\title{
Optimal weight design problem of spur gears
}

\author{
Nguyen Anh My ${ }^{1,2}$, Le Quang Phu Vinh ${ }^{1,2}$, Vo Thanh Binh ${ }^{1,2}$, Nguyen Ngoc Minh ${ }^{1,2, *}$
}

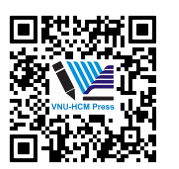

Use your smartphone to scan this QR code and download this article

${ }^{1}$ Department of Engineering Mechanics, Faculty of Applied Science, Ho Chi Minh city University of Technology

${ }^{2}$ Vietnam National University Ho Chi Minh city

\section{Correspondence}

Nguyen Ngoc Minh, Department of Engineering Mechanics, Faculty of Applied Science, Ho Chi Minh city University of Technology

Vietnam National University Ho Chi Minh city

Email: nguyenngocminh@hcmut.edu.vn

History

- Received: 16-11-2020

- Accepted: 02-3-2021

- Published: 15-3-2021

DOI : 10.32508/stdjet.v4i1.792

\section{Check for updates}

\section{Copyright}

(c) VNU-HCM Press. This is an openaccess article distributed under the terms of the Creative Commons Attribution 4.0 International license.

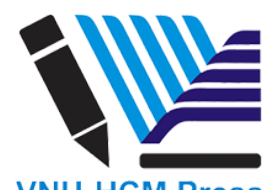

ABSTRACT

Gear is one of the most common and important components in machinery. Evaluation on durability of gears plays crucial role in the assessment of the whole system reliability and service life. For other parts like shafts, the gears also act as loads. Therefore, dimensions and weight of the gears should be reduced as much as possible, contributing the size and weight reduction of the whole systems, which is essential to be cost-effectiveness. The current research focuses on optimal weight design problem of spur gears, such that the weight is minimized under the constraints taken from working conditions. The weight is a function of six variables, i.e. face width, shaft diameter of pinion, shaft diameter of gear, number of teeth on pinion, module and hardness. Constraints are derived based on AGMA standard and engineering handbooks, including the bending strength, the surface fatigue strength, the interference condition, the condition for uniform load distribution, the torsional strength of shaft on pinion and gear, and the center distance. The set of optimum design variables is determined by the heuristic algorithm Grey Wolf Optimizer (GWO). The accuracy and efficiency of the GWO in the optimal weight design problem of spur gears are assessed based on comparison with other popular methods, such as Genetic Algorithm (GA), Particle Swarm Optimization (PSO) and Simulated Annealing (SA). It is noted that in previous works, some of the constraints are still violated. Therefore, a penalty term is taken into the objective function, such that any set of design variables that violates constraints will be considered as "unfit" by the algorithm. It is demonstrated that using the proposed approach by current work, the optimal weight and the corresponding set of design variable are very close to reference data. Yet the advantage of the proposed approach is exhibited in the fact that all of the constraints are satisfied.

Key words: Spur gear, optimal weight design, constrained optimization, Grey Wolf Optimizer

\section{INTRODUCTION}

Gears are widely found in mechanical power transmission systems, which in turn are essential in many fields of applications such as cars, motorbikes, airplanes and machines. Traditionally, the gear design process involves lots of empirical formulas for tooth bending strength, tooth surface fatigue strength, interference, etc. According to handbooks and guidelines, e.g. see references ${ }^{1,2}$, the designer firstly chooses the values of some certain parameters, then the conditions are verified one by one. If any of the conditions (e.g. tooth bending strength or tooth surface fatigue strength) is not satisfied, the process has to be repeated with new choice of parameters. Although the computation can be much accelerated with the aid of computers, the traditional procedure is limited in the sense that the outcome is an admissible design but may not be an optimum one. Therefore, an optimization-based process is required to determine the set of design variables that simultaneously satisfy the conditions.

Applications of optimization methods in gear design have been reported by various authors. Tong and
Walton ${ }^{3}$ focused on minimization of the centre distance or gear volume (separately) for internal gears, using three design variables. Zarefar and Muthukrishnan ${ }^{4}$ proposed an adaptive random-search algorithm to minimize the weight of helical gear weight with four variables (module, helix angle, umber of pinion teeth and face width). The problem of optimal weight design of spur gears under constraints such as bending strength of gear, torsional strength of shafts was formulated and solved by Yokota et al. ${ }^{5}$, with the aid of Genetic Algorithm (GA), in which the objective function (weight) is calculated based on five variables (module, face width, shaft diameter of pinion, shaft diameter of gear, and the number of pinion teeth). Savsani et al. ${ }^{6}$ further extended the problem by considering the sixth design variable (hardness). In fact, the hardness is not involved in the calculation of objective function (i.e. weight), but contributes in the computation of constraints. Two heuristic algorithms, i.e. Particle Swarm Optimization (PSO) and Simulated Annealing (SA) were also investigated by Savsani et al. ${ }^{6}$. However, the "optimum results" in both Yokota et al. ${ }^{5}$ and Savsani et al. ${ }^{6}$ still lead to vi- 
olation of some certain conditions. Miller et al. ${ }^{7}$ employed GA to investigate the influence of profile shift on the spur gear pair optimization.

The gear weight optimization problem involves many design variables of different types, including both discrete and continuous numbers, and has to satisfy multiple constraints. Meta-heuristic algorithms are effective for such a problem. Recently, the nature-inspired Grey Wolf Optimizer (GWO) has been proposed by Mirjalili et al. ${ }^{8}$, which possesses many desirable properties, such as simple calculation, effective both in global and local search. Especially, except for basic parameters such as number of agents and number of iterations which are needed in any heuristic algorithms, GWO does not require extra parameters. It is emphasized that parameters controlling cross-over and mutation operators are needed by GA. In PSO, control parameters are demanded to compute the velocity. For SA, parameters that govern the cooling process are requested. With its potential, GWO has been intensively investigated in various applications, such as electric engineering ${ }^{9}$, earthquake engineering ${ }^{10}$, image processing ${ }^{11}$ and machine learning ${ }^{12,13}$. In this paper, the GWO is employed in finding optimal weight design of single-stage spur gear. Constraints are derived based on AGMA standard ${ }^{14}$. It is noted that AGMA standard was also considered by previous authors ${ }^{5,6}$ but the derivation were not explicitly presented. A computer program with graphical-user interface, written in Python, is also developed in the current work, which can be served for educational purpose.

This report is organized as follows. Right after the Introduction is the second Section, which presents the formulation of the problem. The third Section is reserved for a brief on GWO. Results and discussion are provided in the fourth Section. Finally, concluding remarks are drawn in the last section.

\section{PROBLEM FORMULATION}

The optimal weight design problem of spur gears was early proposed by Yokota et al. ${ }^{5}$, in which the weight is calculated as a function of five design variables: face width $b[\mathrm{~mm}]$, shaft diameter of pinion $d_{1}[\mathrm{~mm}]$, shaft diameter of gear $d_{2}[\mathrm{~mm}]$, number of teeth on pinion $Z_{1}$ and module $m[\mathrm{~mm}]$. The problem was later extended by Savsani et al. ${ }^{6}$, in which the sixth design variable, i.e the Brinell hardness $H$ is added. Some modifications on constraints were also made. Both Yokota et al. ${ }^{5}$ and Savsani et al. ${ }^{6}$ are based on AGMA standard; however the derivation of constraints were not explicitly presented. Importantly, their results still lead to violation of some constraints.
The number of design variables depend on the chosen geometry of the gear pair. In this work, for better comparison, the geometry and the set of design variables are selected following the references ${ }^{5,6}$.

Geometry of the single - stage spur gear pair is given in Figure 1. The objective function (weight) is computed in gram as follows

$$
\begin{aligned}
& W=\frac{\pi}{4} \frac{\rho}{1000} \times \\
& {\left[{ }^{2} m^{2} Z_{1}^{2}(1+i)^{2}-\left(D_{i}^{2}-d_{0}^{2}\right)\left(1-b_{w}\right)\right]} \\
& -\frac{\pi}{4} \frac{\rho}{1000}\left[n d_{p}^{2} b_{w}+\left(d_{1}^{2}+d_{2}^{2}\right) b\right]
\end{aligned}
$$

The design space is defined by the followings. Real values:

$$
20 \leq b \leq 32 ; 10 \leq d_{1} \leq 30 ; 30 \leq d_{2} \leq 40
$$

Integer values:

$$
18 \leq Z_{1} \leq 25 ; 200 \leq H \leq 400
$$

Discrete values:

$$
m \in\{2.75,3,3.5,4\}
$$

Table 1: Values of input quantities ${ }^{6}$

\begin{tabular}{lll}
\hline Symbol & Quantity & Value \\
$K_{r}$ & Bending reliability factor & 0.814 \\
$K_{m s}$ & Mean stress factor & 1.4 \\
$K_{0}$ & Overload factor & 1 \\
$K_{m}$ & Mounting factor & 1.3 \\
$C_{p}$ & Elasticity coefficient & 191 \\
$C_{l}$ & Surface fatigue life factor & 1 \\
$C_{r}$ & Surface reliability factor & 1 \\
$\phi$ & Pressure angle & 250 \\
$i$ & Gear transmission ratio & 4 \\
$\rho$ & Density of gear material & $8 \mathrm{mg} / \mathrm{mm}^{3}$ \\
$P$ & Powers to be transmitted & $7.5 \mathrm{~kW}$ \\
$n$ & Number of drilled holes & 6 \\
$\sigma$ & Gear material strength & $293.3 \mathrm{MPa}$ \\
$y$ & Lewis tooth form factor & 0.102 \\
$K_{w}$ & Shaft shear strength & $19.62 \mathrm{MPa}$ \\
\hline$N_{1}$ & Load factor & 0.8 \\
\hline
\end{tabular}

The input quantities are adopted as in Table 1. Following references ${ }^{5,6}$, the other parameters in Equation (1) are determined by 

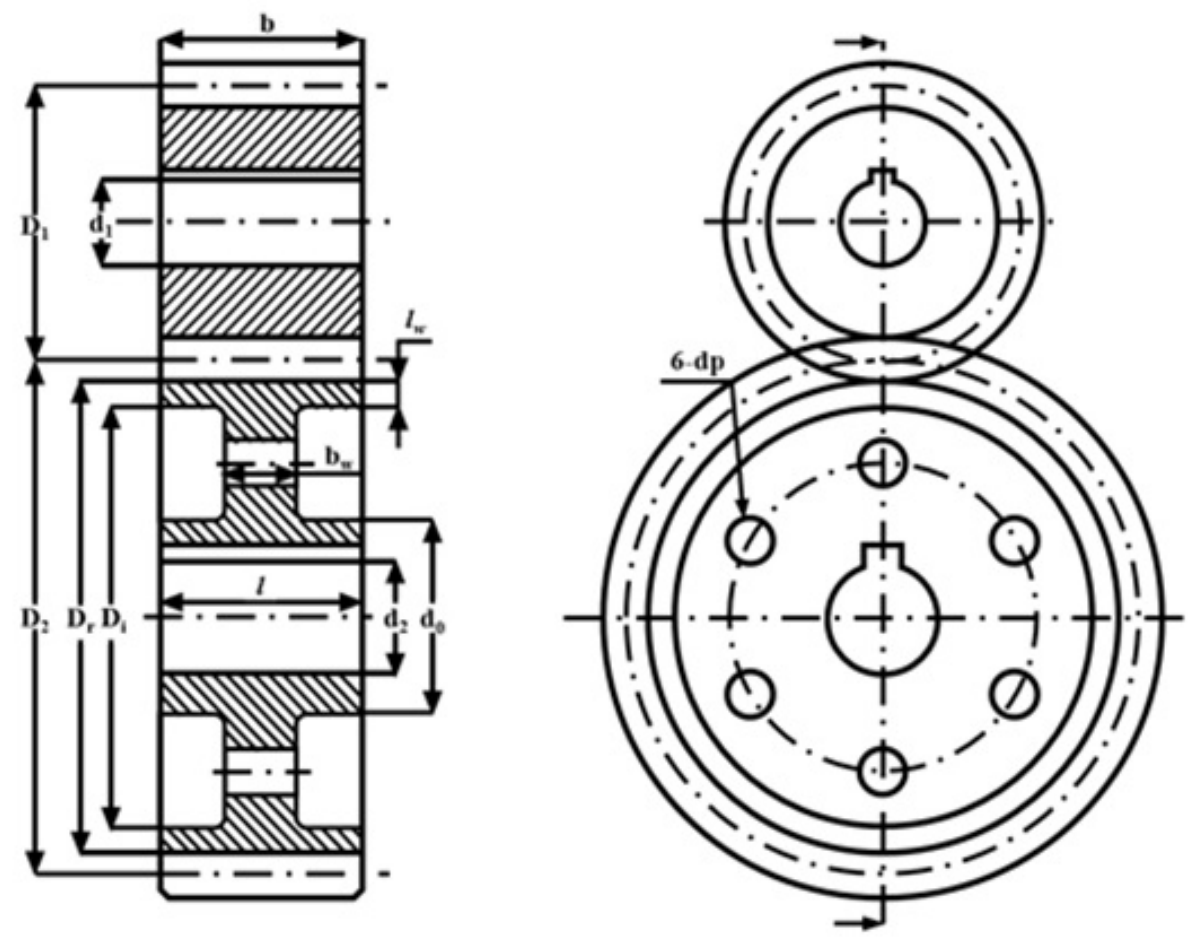

Figure 1: Geometry of the single-stage spur gear pair

$l_{w}=2.5 m ; b_{w}=3.5 m$;

$D_{r}=m\left(i Z_{1}-2.5\right) ; D_{i}=D_{r}-2 l_{w}$;

$d_{0}=d_{2}+25 ; d_{p}=0.25\left(D_{i}-d_{0}\right)$

$D_{1}=m Z_{1} ; D_{2}=i m Z_{1} ; Z_{2}=i Z_{1} ; N_{2}=\frac{N_{1}}{i}$ (3)

In addition, the below constraints are considered.

- Bending fatigue strength

The bending stress taking into the fatigue strength is evaluated based on AGMA standard ${ }^{14}$ as

$$
\sigma=\frac{F_{t}}{m b J} K_{v} K_{0} K_{m}
$$

where $F_{t}$ is the tangential load which can be calculated from the power

$$
F_{t}=\frac{1000 P}{v}[N] .
$$

The velocity $v$ is obtained by converting $N_{1}$ from "round-per-minute" to "meter-per-second". The velocity factor $K_{v}$ is estimated as

$$
K_{v}=\frac{78+\sqrt{196.85 v}}{78}
$$

The relation between Lewis geometry factor $J$ and the number of teeth $Z_{1}$ is given in Figure 3 .
The bending stress must not exceed the permissible value

$$
\sigma \leq[\sigma]=S_{n} C_{s} K_{r} K_{m s}
$$

in which $S_{n}=1.7236 \mathrm{H}$. The surface factor $C_{S}$ is determined from the Brinell hardness $H$ using the graph in Figure 2.

From Equations (3) and (5), the first condition is written by

$$
G_{1}=\frac{S_{n} C_{s} K_{r} K_{m s} b J m}{K_{v} K_{0} K_{m}} \geq F_{t}
$$

- Surface fatigue strength

Similar to the bending fatigue strength, the condition for surface fatigue strength is written based on AGMA standard ${ }^{14}$ as follows

$$
G_{2}=\frac{S_{f e}^{2} C_{l}^{2} C_{r}^{2} b D_{1} I}{C_{p}^{2} K_{v} K_{0} K_{m}} \geq F_{t}
$$

Here, the quantities $S_{f e}$ and $I$ are computed by

$$
S_{f e}=2.8 H-69 ; I=\frac{i \sin \phi \cos \phi}{2(i+1)}
$$

- Interference condition 


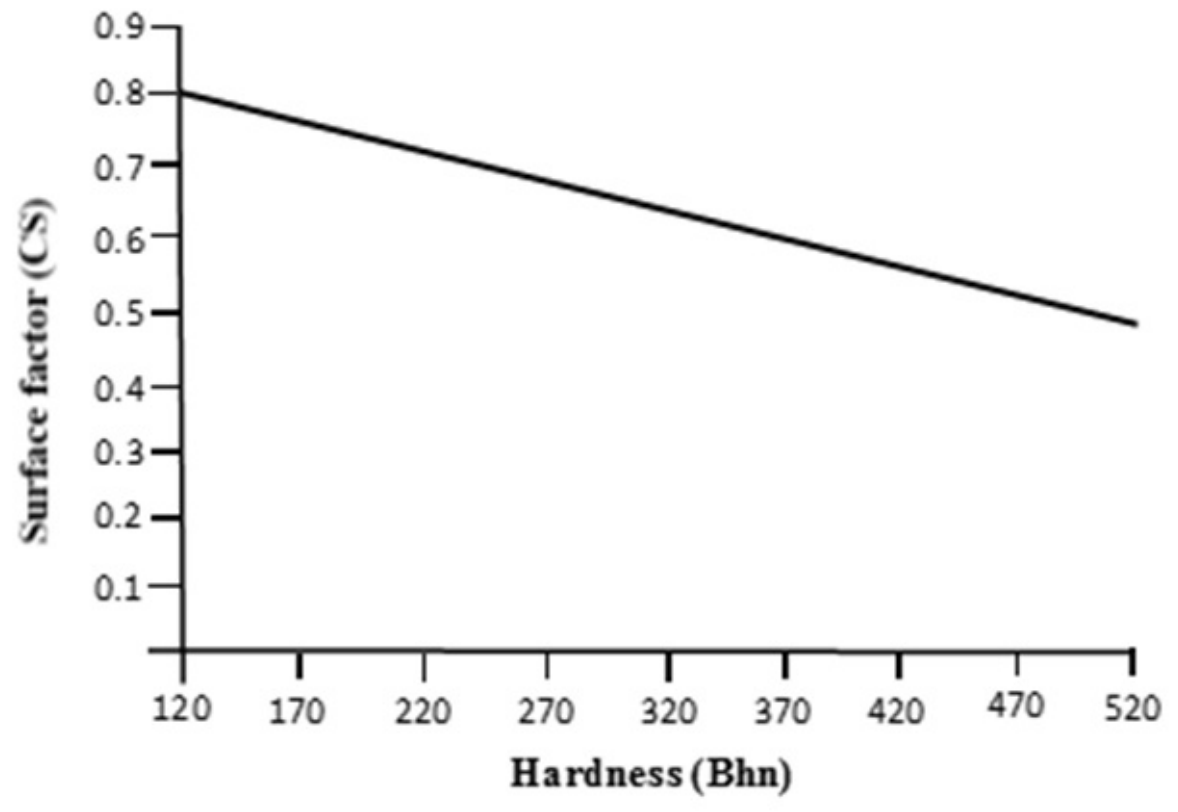

Figure 2: Relation between the surface factor $\mathrm{Cs}$ and the Brinell hardness $\mathrm{H}$

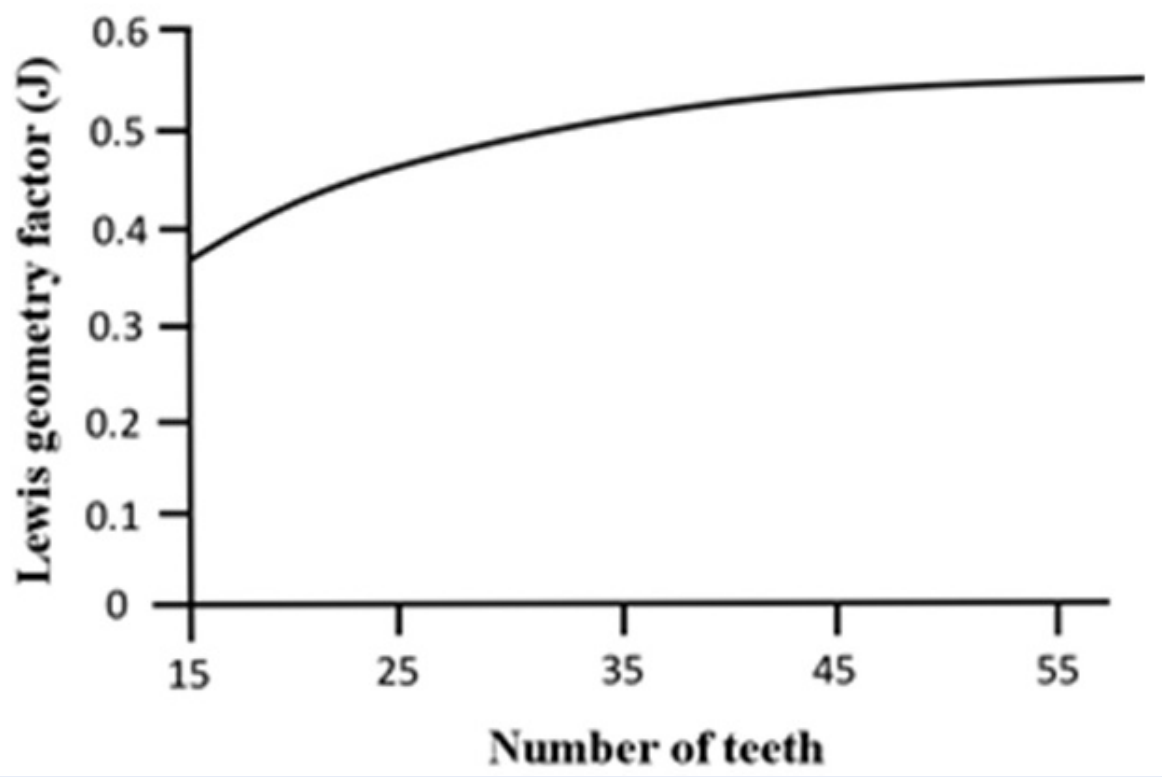

Figure 3: Relation between the Lewis geometry factor $\mathrm{J}$ and the number of teeth $\mathrm{Z}_{1}$ 
According to design handbooks ${ }^{2,15}$ the below condition has to be satisfied to avoid interference

$$
G_{3}=\frac{2 m}{\sqrt{1+\frac{Z_{2}}{Z_{1}}\left(\frac{Z_{2}}{Z_{1}}+2\right) \sin ^{2} \phi-1}} \leq Z_{1}
$$

- Condition for uniform load distribution

Uniform load distribution is preferred in gear design. The following rule of thumb ${ }^{2,15}$ is adopted

$$
8 \leq G_{4}=\frac{b}{m} \leq 16
$$

- Torsional strength of shafts

In order to ensure that the torsional strength shaft is not exceeded, the shaft diameter of pinion should satisfy the requirement ${ }^{1,14}$

$$
d_{1}^{3} \geq \frac{T}{0.2 \tau},
$$

in which $\tau$ is the allowable shear stress of shaft (see Table 1). The torque $T$ (unit: N.mm) is computed by

$$
T=\frac{9.55 \times 10^{6} \mathrm{P}}{N_{1}} .
$$

Substitute Equation (13) into (12), the condition for the shaft diameter of pinion is obtained

$$
G_{5}=d_{1}^{3} \geq \frac{4.78 \times 10^{7} P}{\tau N_{1}} .
$$

The condition for the shaft diameter of gear is determined analogously

$$
G_{6}=d_{2}^{3} \geq \frac{4.78 \times 10^{7}}{\tau N^{2}} .
$$

- Center distance

The distance between centers of the gear pairs is calculated by

$$
a=\frac{D_{1}+D_{2}}{2}=\frac{(1+i) m Z_{1}}{2}
$$

It is recommended that this value should be larger than a lower bound ${ }^{1}$

$$
G_{7}=\frac{(1+i) m Z_{1}}{2} \geq 100 m
$$

It is remarked that the seven constraints presented in Equations $(8,9,11,12,15,16,18)$ were also considered by reference ${ }^{6}$, although the derivation was not explicitly mentioned.

\section{METHODOLOGY: GREY WOLF OPTIMIZER (GWO) FOR CONSTRAINED OPTIMIZATION}

$\mathrm{GWO}^{8}$ is inspired by the social hierarchy of grey wolf. Here, the social rank of each wolf is based on its fitness. The three fittest wolves in history are named as the alpha $(\alpha)$, the beta $(\beta)$, and the delta $(\delta)$, respectively. They are leaders. The rest of the population is called omegas. During the hunting process, i.e. finding the optimum solution, the omega wolves follows the three leaders. Position of an arbitrary omega wolf at the current iteration, $t+1$, is updated by

$$
\mathrm{X}(t+1)=\frac{1}{3}\left(\mathrm{X}_{1}+\mathrm{X}_{2}+\mathrm{X}_{3}\right)
$$

It is noted that components of "position vector" $\mathbf{X}$ are the design variables. $\mathbf{X}_{1}, \mathbf{X}_{2}, \mathbf{X}_{3}$ are some positions in the design space, which are in the surroundings of the three dominant wolves, i.e. the alpha, the beta, and the delta, respectively. For example, $\mathbf{X}_{1}$ is calculated by

$$
\mathrm{X}_{1}=\mathrm{X}_{\alpha}-a_{\alpha} \cdot \mathrm{D}_{\alpha} ; \mathrm{D}_{\alpha}=c_{\alpha} \cdot \mathrm{X}_{\alpha}-\mathrm{X}(t)
$$

The number $a_{\alpha}$ and $c_{\alpha}$ are determined by

$$
a_{\alpha}=s\left(2 r_{1}-1\right) ; c_{\alpha}=2 r_{2},
$$

where $r_{1}$ and $r_{2}$ are two real random values from 0 to 1. The value of $s$ gradually decreases from 2 to zero

$$
s=2\left(1-\frac{t}{t_{\max }}\right),
$$

in which $t_{\max }$ is the maximum number of iteration. It should be emphasized that if $\left|a_{\alpha}\right|<1$, the omega wolf will tend to join with the dominant ones to attack the prey (i.e. local search). On the other hand, if $\left|a_{\alpha}\right|>$ 1 , the omega runs away, hopefully to discover a more attractive prey (i.e. global search).

The points $\mathbf{X}_{2}, \mathbf{X}_{3}$ are determined using the same manner as mentioned in Equations (19-20).

The above algorithm of $\mathrm{GWO}^{8}$ is for un-constrained problems. In order to take the constraints into account, the penalty method is employed. If a constraint is violated, the fitness function (see Equation (1)) is added by a penalty term, which should be a large value. By doing so, any set of design variables that leads to violation of constraint will be considered as "not fitted" by the algorithm. It is crucial to select a large value for the penalty term. If the penalty term is small, it is useless. A possible strategy is that at first, the penalty term is set to zero. It is very likely that the obtained solution will violate some of the constraints. Let us call the corresponding weight in this case as " $f_{0}$ ", the penalty term then can be estimated by multiplying " $f_{0}$ " with a factor of 1000 . 


\section{RESULTS AND DISCUSSION}

The proposed GWO algorithm for constrained optimization (the third Section) is implemented in Python to solve the problem of finding the optimal weight design of spur gears (the second Section).

Results obtained by the present GWO algorithm are displayed in Table 2, showing a comparison with those obtained by GA, SA and PSO ${ }^{6}$, for the design space defined in Equations $(2 a, 2 b, 2 c)$. The population size and the maximum number iteration are chosen exactly the same with Savsani et al. ${ }^{6}$, i.e. 20 wolves and 300 iterations. It is observed that both the weight and the corresponding "optimized" set of design variables are quite similar to those reported in reference ${ }^{6}$. However, the notable difference is that the set of design variables determined by GWO satisfy all the constraints. All the results by Savsani et al. ${ }^{6}$, regardless GA, SA or PSO algorithm, still encounter violation of some constraints.

For further demonstration, the ranges of design variables are extended as follows

Real values:

$$
10 \leq b \leq 35 ; 10 \leq d_{1} \leq 30 ; 10 \leq d_{2} \leq 40
$$

Integer values:

$$
18 \leq Z_{1} \leq 25 ; 200 \leq H \leq 400
$$

Discrete values:

$$
m \in\{1,1.25,1.5,2,2.75,3,3.5,4\}
$$

Due to broader ranges of variables, the maximum number of iteration is also increased to 500. Optimized results for the extended design space are presented in Table 3. In this case, the weight obtained by GWO is slightly higher than that by GA, SA, and PSO as reported in Savsani et al. ${ }^{6}$. However, again it is important that some constraints are violated in Savsani et al. ${ }^{6}$, while no violation is encountered by the proposed GWO.

20 wolves and 300 iterations are used to obtain the results in Table 2. By using a computer with Intel(R) Core(TM) i7-10750H CPU @ 2.60GHz and 8.00 GB RAM, the computational time is approximately 15 minutes (no parallel computing is involved). For the example presented in Table 3, 20 wolves and 500 iterations are used. The elapsed time in this case is nearly 20 minutes. Unfortunately, there is no information available on the computational cost in the references ${ }^{5,6}$. Nevertheless, it is reasonable to consider that the current approach is more efficient because the solution is achieved without any violation of constraints.

\section{CONCLUSION}

The meta-heuristic GWO algorithm has been successfully applied to the constrained optimization problem of finding optimal weight design of spur gear. The constraints are derived from working conditions with reference to AGMA standard and engineering handbooks. The problem is challenging, as results reported in previous works by other authors still encounter violation of constraints. The current results show that an optimal set of design variables that satisfy all the constraints can be obtained.

All of the six design variables have their roles. The first five variables are geometry parameters, which directly contribute to the weight (objective function). Although the hardness $H$ does not contribute to the weight, it represents the material strength. Indeed, $H$ is required during evaluation of bending fatigue strength (constraint $G_{1}$ ) and surface fatigue strength (constraint $G_{2}$ ). Loosely speaking, higher value of hardness $H$ leads to higher strength, which allows the reduction of geometry parameters. Therefore, $H$ indirectly affects the total weight. However the manufacturing cost may increase as well. For practical purpose, additional constraint on manufacturing cost can be included.

In GWO algorithm, the position of each wolf is updated based on the information of the three best wolves, i.e. the alpha, the beta, and the delta. Although the technique may enhance the exploitation, it requires more calculation and more storage space. It is noted that in GA, the update of each chromosome does not involve information of the best solution. In PSO, two special solutions, i.e. the current best and worst ones, are required. Furthermore, it is argued by Gao and Zhao ${ }^{16}$ that the role of alpha, the beta, and the delta should not be the same as in Equation (19). Equation (19) should be rewritten as a weighted average, in which the influence will be assigned from highest to lowest value to the alpha, the beta and the delta, respectively. However, the task of improving GWO is not within the scope of the current work.

\section{ACKNOWLEDGEMENT}

This work is financially supported by the Ho Chi Minh city University of Technology under the grant SVCQ2020-KHUD-48.

\section{LIST OF ABBREVIATIONS}

AGMA: American gear manufacturers association GWO: Grey Wolf Optimizer

GA: Genetic Algorithm

SA: Simulated Annealing

PSO: Particle Swarm Optimization

GUI: Graphical User Interface 
Table 2: Comparison of optimization results, with the design space defined in Equations $(2 a, 2 b, 2 c)$

\begin{tabular}{|c|c|c|c|c|}
\hline & $\mathrm{GA}^{6}$ & $\mathrm{SA}^{6}$ & $\mathrm{PSO}^{6}$ & GWO \\
\hline $\begin{array}{l}\text { Weight } \\
\text { [g] }\end{array}$ & 2993.7 & 2993.5 & 2993.5 & 2993.7 \\
\hline $\begin{array}{l}\mathrm{b} \\
{[\mathrm{mm}]}\end{array}$ & 21.999 & 21.997 & 21.999 & 22.000 \\
\hline $\begin{array}{l}\mathrm{d}_{1} \\
{[\mathrm{~mm}]}\end{array}$ & 30 & 30 & 30 & 30 \\
\hline $\begin{array}{l}\mathrm{d}_{2} \\
{[\mathrm{~mm}]}\end{array}$ & 36.751 & 36.742 & 36.768 & 36.753 \\
\hline $\mathrm{Z}_{1}$ & 18 & 18 & 18 & 18 \\
\hline $\begin{array}{l}\mathrm{m} \\
{[\mathrm{mm}]}\end{array}$ & 2.75 & 2.75 & 2.75 & 2.75 \\
\hline $\mathrm{H}$ & 341.46 & 350 & 338 & 352 \\
\hline Violation & $\mathrm{G}_{4}, \mathrm{G}_{6}$ & $\mathrm{G}_{4}, \mathrm{G}_{6}$ & $\mathrm{G}_{4}$ & - \\
\hline
\end{tabular}

Table 3: Comparison of optimization results, with the extended design space defined in Equations (23a, 23b, 23c)

\begin{tabular}{lllll}
\hline & $\mathrm{GA}^{6}$ & $\mathrm{SA}^{6}$ & $\mathrm{PSO}^{6}$ & $\mathrm{GWO}$ \\
$\begin{array}{l}\text { Weight } \\
{[\mathrm{g}]}\end{array}$ & 1664.3 & 1661.1 & 1661.1 & 1664.9 \\
{$[\mathrm{~mm}]$} & & & & 26.90 \\
$\mathrm{~d}_{1}$ & 26.87 & 26.74 & 26.73 & 30 \\
{$[\mathrm{~mm}]$} & 30 & 30 & 30 & \\
$\mathrm{~d}_{2}$ & & & & 36.76 \\
{$[\mathrm{~mm}]$} & 36.75 & 36.743 & 36.74 & 18 \\
$\mathrm{Z}_{1}$ & 18 & 18 & 18 & 2 \\
$\mathrm{~m}$ & 2 & 2 & 2 & 400 \\
{$[\mathrm{~mm}]$} & & & & \\
$\mathrm{H}$ & 400 & 400 & 400 & - \\
\hline Violation & $\mathrm{G}_{2}, \mathrm{G}_{6}$ & $\mathrm{G}_{2}, \mathrm{G}_{6}$ & $\mathrm{G}_{2}, \mathrm{G}_{6}$ & \\
\hline
\end{tabular}

\section{CONFLICT OF INTEREST}

There is no conflict of interest.

\section{CONTRIBUTION OF EACH AUTHOR}

Nguyen Anh My contributes in analysis of the results and prepares the first version of the manuscript.

Le Quang Phu Vinh develops the python code, including the GUI, and run the code to obtain results.

Vo Thanh Binh studies the AGMA standard and derive the constraint equations. He also helps to prepare the first version of the manuscript.

Nguyen Ngoc Minh contributes in ideas brainstorming, data checking, proofreading and editing of the manuscript.

\section{REFERENCES}

1. Chất $T$, Uyển LV. Tính toán thiết kế hệ dẫn động cơ khí: Nhà xuất bản giáo dục. 2008;.

2. Shigley JE, Mischke CR, Brown Jr. TH. Standard Handbook of Machine Design: McGraw-Hill Education. 2004;.

3. Tong BS, Walton D. The optimisation of internal gears. International Journal of Machine Tools and Manufacture. 1987;27(4):479-489. Available from: https://doi.org/10.1016/ S0890-6955(87)80020-2.

4. Zarefar H, Muthukrishnan SN. Computer-aided optimal design via modified adaptive random-search algorithm. Computer-aided design. 1993;40:240-248. Available from: https://doi.org/10.1016/0010-4485(93)90055-S.

5. Yokota T, Taguchi T, Gen M. A solution method for optimal weight design problem of the gear using Genetic Algorithms. Computers \& Industrial Engineering. 1998;35:523-526. Available from: https://doi.org/10.1016/S0360-8352(98)00149-1. 
6. Savsani V, Rao RV, Vakharia DP. Optimal weight design of a gear train using particle swarm optimization and simulated annealing algorithms. Mechanism and Machine Theory. 2009;45:531-541. Available from: https://doi.org/10.1016/j. mechmachtheory.2009.10.010.

7. Miler D, Loncar A, ZD, and Domitran Z. Influence of profile shift on the spur gear optimization. Mechanism and Machine Theory. 2017;117:189-197. Available from: https://doi.org/10. 1016/j.mechmachtheory.2017.07.001.

8. Mirjalili S, Mirjalili SM, Lewis A. Grey Wolf Optimizer. Advances in Engineering Software. 2014;69:46-61. Available from: https://doi.org/10.1016/j.advengsoft.2013.12.007.

9. Lakum A, Mahajan V. Optimal placement and sizing of multiple active power filters in radial distribution system using grey wolf optimizer in presence of nonlinear distributed generation. Electric Power System Research. 2019;173:281-290. Available from: https://doi.org/10.1016/j.epsr.2019.04.001.

10. Song X, Tang L, Zhao S, Zhang X, Li L, Huang J, et al. Grey Wolf Optimizer for parameter estimation in surface waves. Soil Dynamics and Earthquake Engineering. 2015;75:147-157. Available from: https://doi.org/10.1016/j.soildyn.2015.04.004.
11. Zhang S, Zhou Y. Template matching using grey wolf optimizer with lateral inhibition. Optik. 2017;130:1229-1243. Available from: https://doi.org/10.1016/j.ijleo.2016.11.173.

12. Emary E, Zawbaa HM, Grosan C, Hassenian AE. Binary grey wolf optimization approaches for feature selection. Neurocomputing. 2016;172(8):371-381. Available from: https://doi. org/10.1016/j.neucom.2015.06.083.

13. Eswaramoorthy S, Sivakumaran N, Sekaran S. Grey wolf optimization based parameter selection for support vector machines. COMPEL - The international journal for computation and mathematics in electrical and electronic engineering. 2016;35(5):1513-1523. Available from: https://doi.org/10. 1108/COMPEL-09-2015-0337.

14. American National Standard: Fundamental Rating Factors and Calculation Mehods for Involute Spur and Helical Gear Teeth: American Gear Manufacturers Association. 2001;

15. Norton RL. Machine Design - An integrated approach: Pearson. 2020;

16. Gao ZM, Zhao J. An improved Grey Wolf Optimization algorithm with variable weights. Computational Intelligence and Neuroscience. 2019;2019:2981282. PMID: 31281334. Available from: https://doi.org/10.1155/2019/2981282. 


\title{
Tối ưu hóa khối lượng của cặp bánh răng trụ răng thẳng
}

\author{
Nguyễn Anh Mỹ ${ }^{1,2}$, Lê Quang Phú Vinh ${ }^{1,2}$, Võ Thanh Bình ${ }^{1,2}$, Nguyễn Ngọc Minh ${ }^{1,2, *}$
}

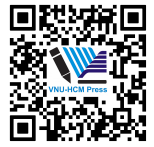

Use your smartphone to scan this QR code and download this article

${ }^{1}$ Bồ môn Cơ kỹ thuât, Khoa Khoa hoc Ưng dung, Trường Đại học Bách khoa Thành phố Hồ Chí Minh

${ }^{2}$ Đại học Quốc gia Thành phố Hồ Chí Minh

Liên hệ

Nguyễn Ngọc Minh, Bộ môn Cơ kỹ thuật, Khoa Khoa học Ứng dụng, Trường Đại học Bách khoa Thành phố Hồ Chí Minh

Đại học Quốc gia Thành phố Hồ Chí Minh

Email: nguyenngocminh@hcmut.edu.vn

Lịch sử

- Ngày nhận: 16-11-2020

- Ngày chấp nhận: 02-3-2021

- Ngày đăng: 15-3-2021

DOI : 10.32508/stdjet.v4i1.792

\section{Check for updates}

\section{Bản quyền}

(c) ĐHQG Tp.HCM. Đây là bài báo công bố mơ được phát hành theo các điều khoản của the Creative Commons Attribution 4.0

International license.

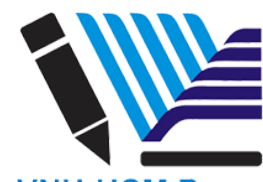

VNU-HCM Press

\section{TÓM TẮT}

Bánh răng là chi tiết phổ biến và quan trong trong máy móc. Việc đánh giá độ bền của bánh răng vì thế có ý nghĩa thiết yếu đối với độ tin cậy và tuổi thọ làm việc của toàn hệ thống. Đối với các chi tiết khác, chẳng hạn như trục, bánh răng còn đóng vai trò là tải. Vi vậy, kích thước và khối lượng bánh răng cần được hết sức tiết giảm, nhằm làm thu gọn kích thước và khối lượng của toàn hệ thống, từ đó giảm được chi phí. Nghiên cứu hiện tại tập trung vào tối ưu hóa khối lượng của cặp bánh răng tru răng thẳng, xét đến những ràng buộc xuất phát từ điều kiệ làm viẹc. Các biến thiết kế được lựa chọn là bể rộng răng, đường kính trục ở bánh răng chủ động, đường kính trục ở bánh răng bị động, số răng ở bánh răng chủ động, mô-đun và độ cứng. Các ràng buộc được xây dựng với tham khảo từ tiêu chuẩn AGMA và sổ tay thiết kế, bao gồm độ bền uốn, độ bền mỏi tiếp xúc, điều kiện ăn khớp, điều kiện phân bố tải trọng khi tiếp xúc, độ bên xoắn trục tại vị trí lắp bánh răng và khoảng cách truc. Bô giá trị biến thiết kế tối ưu được xác định thông qua giải thuâat tìm kiếm sói xám (Grey Wolf Optimizer - GWO). Tính chính xác và hiệu quả của GWO được so sánh với các phương pháp khác như giải thuật di truyền (Genetic Algorithm - GA), giải thuật bầy đàn (Particle Swarm Optimization - PSO) và giải thuật mô phỏng luyện kim (Simulated Annealing - SA). Kết quả thu được từ các nghiên cứu trước đều ghi nhận sự vi phạm đối với một vài điều kiện ràng buộc. Trong nghiên cứu hiện tại, hàm mục tiêu được cộng thêm thành phần "phạt" để đảm bảo bất kỳ tập hợp biến thiết kế nào vi phạm điê̂u kiện ràng buộc đêu bị thuật toán coi là không phù hợp. Kết quả cho thấy, lời giải thu được từ phương pháp đề xuất trong nghiên cứu hiện tại có sự tương đồng tốt với các tài liệu tham khảo, cả về khối lượng bánh răng và các giá trị biến thiết kế tương ứng. Ưu điểm của nghiên cứu hiện tại được thể hiện qua việc tất cả các điều kiện ràng buộc đều được thỏa mãn.

Từ khoá: Bánh răng tru răng thẳng, thiết kế tối ưu khối lượng, tối ưu hóa có ràng buộc, Grey Wolf Optimizer
Trích dẫn bài báo này: Mỹ N A, Vinh $L Q P, B i ̀ n h ~ V T$, Minh N N. Tối ưu hóa khối lượng của cặp bánh răng trụ răng thẳng. Sci. Tech. Dev. J. - Eng. Tech.; 4(1):671-679. 